\title{
Radical Book History \\ E. P. Thompson and \\ The Making of the English Working Class
}

\author{
Antoinette Burton \\ -................ \\ Professor of History, University of Illinois at Urbana-Champaign
}

\section{Radically Bookish: The Afterlives of The Making of the English Working Class}

This special issue on E. P. Thompson's The Making of the English Working Class (1963) grew out of a symposium I organized at the University of Illinois, Urbana-Champaign in October 2013 to commemorate the fiftieth anniversary of the book's publication. I am, on the face of it, one of the least likely modern British historians to be organizing such an event. I can remember the first time I held the weighty tome in my hands: I was a junior in college, in the fall of 1982, and it was on the syllabus for a course I was taking on Victorian Britain, taught by Jonathan Schneer at Yale University. As did many feminist and postcolonial historians of my generation, I struggled with what I saw as Thompson's indifference to women and gender (oh, those deluded followers of Joanna Southcott!) and his incapacity to see the evidence of race and empire in his sources even when they cried out from below the footnote line for all to see.

In the interim, a good many careers have been given over to defending, embracing, overturning, and tweaking the monumental claims made by this monumental book, the result of at least a decade of archival research and methodological rethinking. The Making was and is a palimpsest, a rich and textured parchment that has been scraped and used again. It has passed through so many hands that it has become a kind of recycled commons: shared if not fully subscribed to by multiple users who, whether they reject it or extend it or only read the preface, accord it an often storied status in their intellectual formation. Indeed, there have been a raft of conferences large and small in the past two years dedicated to wrestling with the questions raised by Thompson's big book and by extension, by his larger body of work-evidence of The Making's long life and its role in shaping the intellectual lives of several generations of readers. 
I would not say I have made my peace with The Making. Rather, teaching it as I have off and on in the 1990s and 2000s has given me a renewed appreciation for its durability and for its capacity to call out and make audible the specificities of whatever present moment in which it is being read. Teaching parts of the book in the fall of 2009 as the detritus of the global fiscal crisis fell all around us, hearing, perhaps for the first time, the historically particular iteration of humanism that shapes his account of working class politics, was especially poignant-and particularly so for scholars of my generation, for whom humanism has not, perhaps, felt like an intellectual desideratum or an ethical desideratum for a very long time. Like all radical history worth its salt, Thompson's work still has a lot to show us, as much about the present as about the pasts he so painstakingly evokes in The Making.

The articles presented here are less about Thompson the man or even Thompson the historian than they are about The Making of the English Working Class as a book itself. The bookish-ness of our collective project feels especially urgent. It seems important, in other words, at this juncture in the history of the book itself as a form, whether virtual or real, to be reminded that Thompson's book was here, and still is. Its monumentality alone secures for it a significant, if not permanent, place in history and historiography alike. But we nominated it for reconsideration on the occasion of its fiftieth anniversary because though - as with all those whose anniversaries and birthdays we fete-it has had a good run, we are not quite sure how long it will last. Will it be here in ten years time, in twenty? Will it remain, and in what form, after we who are gathered to witness its work in the world are gone? Are the ways it resonates now predictors of its long-term fate? Does its value reside chiefly in its function as an allegory for the politics and thinking of its time-and as a palimpsest for ours? Here its radical bookishness is key, for it hails the past and the present and the dynamic relationship between the two. That was a dynamic that Thompson well understood. Yet the pressure of contemporary history on the writing of the past remains a radical claim. As both an intellectual project and as a material object, then, The Making has weight. It is that weight, rather than a rehearsal of its arguments or contents, that contributors to this volume were asked to consider. In the articles that follow, scholars engage The Making as a storehouse of histories past and as a physical object: something that was materialized in print, that circulated and was consumed, carried around like so much baggage, refit and repurposed and likely, yes, at least in its original hardcover edition, even used as a doorstop. Beyond its contents, it matters as material culture: as a hefty, adamantine object whose future trend lines are uncertain because this is the age of the disappearance of just such books, at least in their form between two covers.

Any discussion of The Making today is surely elegiac because so few readers the world over will hold books like it in their hands, going forward. They will not feel the weight of history in the way that it has long been possible to do, not for all, but for some, in global terms. No Kindle book will deliver 
history in that historically specific way and, I daresay, no Kindle book works so well as a doorstop either. E-readers offer many other possibilities, but the touch of finger on paper, the vulnerability to the pencil mark, the signature of the author him- or herself, the sheer bulk and heaviness of mountains of tracts and pamphlets read and cited, digested and regurgitated-these are things that The Making archives, for now. With the book in hand, one feels the labor of this particular archive story. And one remembers what a struggle social history had to register as legitimate history, so that the book's very heft is evidence of how it had to prove its mettle against the traditional narratives it aimed to challenge.

Our engagement with The Making of the English Working Class at the symposium and in the essays below was the culumination of three years of thinking about "world histories from below" - a concept at least partially indebted to Thompsonian social history. We began by creating a shared vocabulary about the "global" and the "below"; then, under the intellectual leadership of Kathy Oberdeck, we moved to exploring the ways in which regular people, from shack dwellers to slaves to urban workers, demanded a role in shaping the structure of their worlds, especially around shelter, sanitation, and services. In the context of the Thompson anniversary, we focused on the entanglements of the natural world, capitalism, and public space as subjects of "grassroots" history.

In the retrospective shadow of The Making, all of the 2013 events surrounding the book (ours included) look a little belated: we are all engaged in a re-visioning of Thompson's and other Left historians' mid-twentiethcentury commitment to the below that tells us as much about our present conditions as about any pasts we wish to recover. What we learned in these three years by thinking through world history from the bottom up is not that there is no accessible below, or that there is no a priori global, but that the meanings of both have to be talked through, argued about, and debated because these questions are never settled.

What is impressive is how Thompson's book continues to be one fulcrum for such engagement. What was unanticipated for me, personally, was how surprising it is that The Making has the capacity to tap into and re-reconfirm our desire for history, capital H-even allowing for our dissatisfaction with it, and even allowing for all the skepticism and paranoia that any engagement with a discipline like History entails. ${ }^{1}$ Coming to terms not simply with the variety of impacts the book has had but also with the equal variety of intellectual, political, personal, and even visceral experiences it set into motion is itself a consequence of Thompson's own preoccupation with the kind of consciousness that he believed shaped collectivities in symbolic and material ways.

James Barrett starts us off with the long view of The Making's influence, specifically by setting out the impact it had on US radical thinking at a formative moment in the country's history. For Barrett the socialist humanism of that time was a profoundly emotional experience as well as a profes- 
sional and political one-a point that echoes the powerfully personal ways in which many people tend to remember their own encounters with The Making. In Ann Curthoys's article we see how The Making actually traveledand how it did not-to Australia, following the histories of those whose radical protest took them to new shores and involved them in white settler histories of the kind Thompson himself scarcely took notice of. She reminds us of the battles between Thompson and George Rudé and of the range of social histories beyond The Making that seemed to serve the needs of antipodean histories better. Taken together, these first two pieces remind us of the material/ist histories of radicalism —as both a set of utopian possibilities and as a set of more unevenly lived experiences-that The Making intersected and helped to shape.

Chris Boyer asks challenging questions about the applicability of The Making's concepts to the history of Mexico, focusing on Thompson's use of community to think about the portability of notions of class solidarity when looking at pueblos under the dictatorship of Porfirio Diaz. In so doing he does not so much challenge the universalism of Thompson's claims as he tests the viability of the moral economy and the social cohesion of peasants under the pressure of modernization and ultimately, revolution. Looking at the imperial project from another perspective, Zach Sell poses a question: "In what ways did the English working class fantasize about the American South and colonial India?" His answer, which draws as much on W. E. B. Du Bois as it does on Thompson, focuses on the "world-conquering visions" of slave masters and the movement of capital and bodies between zones of factory and plantation production. Indeed, in the wake of critical race history and postcolonial studies, the absence of attention to race in The Making has preoccupied scholars. Some like Ron Ramdin, have sought equivalencies, as in his 1987 The Making of the Black Working Class in Britain. Caroline Bressey shows us how one might remain grounded in the materialities of class and still capture the multiethnic histories of the late eighteenth and early nineteenth centuries that formed the basis of The Making. Using historical geography as a concept and a method, Bressey assesses the eruptions of race as a category and racialized subjects as agents that can be seen in the making of a presumptively white British working class that Thompson's book archives. In the process, she calls for a reintegration of so-called black British geographies into transnational narratives of British modernity, a landscape that the life and work of the late Victorian radical reformer Catherine Impey so deftly illustrates.

Like Bressey and Sell and Boyer do here, many scholars have sought to map Thompson's concept of class and consciousness and feeling onto earlier centuries. Others, like Barrett and Curthoys, track the influence of The Making forward into the histories and historiographies that followed on from the 1960s. By contrast, Lara Kriegel pulls us into the very moment that the book was written in order to help us appreciate the affective contours of late 1950s Britain, specifically with reference to the "kitchen sink dramas" 
of the day. She reads texts like John Osborne's Look Back in Anger to recover the anomie and sense of hopelessness to be found in the recessive spaces of working class culture at the dawn of post-imperial Britain. In films and texts of the day, the household is a key space where the emotional disappointments of normative proletarian life play out, and a nostalgia for earlier working-class days of the kind that Thompson wrote about is practically palpable in all its gendered forms.

Kriegel ends her article by noting that The Making still has the power to materialize that nostalgia, as is evident by its prominent display in the Tate bookshop during an L. S. Lowry exhibition. Conversely, Isabel Hofmeyr focuses her attention on the negative space around the materialized text: the margins-and marginalia_of the book itself. She lays The Making against Steve Biko's posthumous compilation, I Write What I Like, arguing that they belong to the same reading formations. Each of these oppositional intellectuals hailed readers who engaged passionately with their writings and left indexical traces of their experience of the texts in the marginalia. Those scribblings leave, in turn, a fugitive, ghostly archive of reader response. Copies stolen or overdue, mysterious scratching, even outright theft-these are the archival traces Hofmeyr excavates.

Lest we fetishize the fiftieth anniversary moment, Utathya Chattopadhyaya reminds us of how the legacy of The Making unfolded twenty years after its publication, in the 1983 film Talking History. The film, produced by H. O. Nazareth and with a soundtrack by Spartacus R, puts Thompson in conversation with C. L. R. James at a pivotal moment in the history of internationalism-and in Thatcher's multiracial Britain as well. There are no one-to-one correspondences between The Making and the film, but as Chattopadhyaya points out, James's controlled, witty criticism of the insular European left in the face of eruptions of Third World political rebellion across the globe-eruptions effectively captured by the cut-and-paste newspaper clippings Nazareth's film throws up-reminds us of how resoundingly selfaware Thompson was, yet how deaf he could also be to radical cosmopolitan forms beyond his ken. This, together with the contrapuntal rhythms of Spartacus R's music, underscores the contradictions between the Little Englander character of The Making with Thompson's own particular politics of internationalism.

As we track Thompson's influence in a variety of locations, genres, and reading communities, the limits and possibilities of that peculiar politics are in very much evidence in the articles that follow. Most of the contributors do not do a close reading of The Making; they are more interested in what it has meant to various communities, how it shaped narratives, and how it has reflected the times in which it was written, for better or for worse. If they demonstrate how Thompson's tome remains radically bookish, they are not hagiographical, not by any means. But they do ask what The Making means now and that very question is a form of homage. In that sense, they testify, however unwittingly, to the outsized impact of this big book not just on 
readers who have encountered it in various ways, but on the way historians and literary scholars and many others besides think about community, about reading practice, about class and its multiform histories in the long shadow Thompson's work has left. Taken together, our reflections suggest that, contemporary anxieties about the fate of the book itself as an embodied medium of history notwithstanding-despite the short-term crisis of bookishness in general, in other words-The Making remains an enduring artifact of both English history as it was and the social and cultural history of the book form as we know it.

\section{Notes}

1. I draw here on Alan Berube, My Desire for History: Essays in Gay, Community and Labor History (Chapel Hill: University of North Carolina Press, 2011). 